\title{
RRR- $\alpha$-tocopheryl succinate induces apoptosis in human gastric cancer cells via the NF-кB signaling pathway
}

\author{
YANPEI SUN ${ }^{1}$, YAN ZHAO $^{1}$, LIYING HOU ${ }^{1}$, XUGUANG ZHANG $^{1,2}$, \\ ZHIHONG ZHANG ${ }^{3}$ and KUN WU ${ }^{1 *}$ \\ ${ }^{1}$ Department of Nutrition and Food, Harbin Medical University, Harbin; ${ }^{2}$ Harbin Children's Hospital, Harbin; \\ ${ }^{3}$ Food Processing Institute, Heilongjiang Academy of Agricultural Sciences, \\ Harbin, Heilongjiang, P.R. China
}

Received February 1, 2014; Accepted April 15, 2014

DOI: $10.3892 /$ or.2014.3282

\begin{abstract}
To investigate the effects of the nuclear factor $(\mathrm{NF}) \mathrm{\kappa B}$ signaling pathway on the induction of apoptosis by vitamin E succinate (RRR- $\alpha$-tocopheryl succinate; VES) in human gastric carcinoma cells. Human gastric carcinoma SGC-7901 cells were treated with temperate concentrations of VES and pyrrolidine dithiocarbamate (PDTC), an inhibitor of NF-кB. Cell viability and apoptosis were respectively estimated by methylthiazol tetrazolium (MTT) assay and the Annexin V-FITC method. Western blot analysis was used to evaluate the protein expressions of NF- $\mathrm{\kappa Bp} 65$ and Bcl-2 family members Bcl-2, Bax and cleavage of caspase-3, caspase-9, and poly (ADP-ribose) polymerase (PARP). The DNA-binding activity of NF- $\mathrm{KBp} 65$ was measured by electrophoretic mobility shift assay (EMSA). Reverse transcription and polymerase chain reaction (RT-PCR) was implemented to evaluate the transcription of inhibitor of apoptosis (IAP) genes. Apoptosis assessment showed that VES induces apoptotic cell death in human gastric carcinoma cells. In the following experiments, PDTC $(100 \mu \mathrm{M})$ was used in cell treatment $2 \mathrm{~h}$ before VES. The decreased ratio of the nuclear and cytosolic NF- $\kappa B p 65$ protein level was induced by VES and PDTC reinforced this trend. PDTC treatment significantly enhanced the decrease of NF- $\mathrm{KB}-\mathrm{DNA}$ binding activity induced by VES in human gastric SGC-7901. The decrease in protein expression of Bcl-2 as well as the increase in the protein expression of Bax were induced by VES treatment. The cleavage of caspase- 9 , caspase- 3 and PARP was induced. There was no effect on the gene transcription of c-IAP-1, c-IAP-2, and x-linked IAP (XIAP) compared with the control group, whereas mRNA levels of survivin and the neuronal apoptosis inhibitory protein (NAIP) markedly decreased. Notably, pretreatment with PDTC reinforced all the above VES-induced effects. In conclusion, VES-induced
\end{abstract}

Correspondence to: Professor Kun Wu, Department of Nutrition and Food, Harbin Medical University, 157 Baojian Road, Nangang, Harbin, Heilongjiang 150086, P.R. China

E-mail: wukun_15000@126.com

Key words: vitamin E succinate, NF-кB signaling pathway, gastric carcinoma cells, apoptosis apoptosis in SGC-7901 cells is accompanied by the inhibition of the NF- $\mathrm{KB}$ signaling pathway, including changes in $\mathrm{Bcl}-2$ family members, cleavage of caspases and gene transcription of survivin and NAIP.

\section{Introduction}

Gastric carcinoma is one of the most common causes of cancer-related mortality worldwide; however, there is limited effective clinical treatment for this highly malignant tumor besides surgery and chemotherapy. Furthermore, the treatment outcome remains unsatisfactory as early diagnosis of gastric cancer remains difficult and most patients have already developed metastatic lesions when diagnosed (1). Therefore, it is necessary to search novel agents to treat stomach cancer patients with adverse effects.

An increasing number of publications indicate that vitamin $\mathrm{E}$ succinate (VES), a natural derivative of vitamin $\mathrm{E}$, exhibits powerful anticancer effects in a variety of in vivo and in vitro cancer models (2-7). Our previous studies showed that VES induced apoptosis in SGC-7901 human gastric cancer cells via multiple signaling pathways, including extrinsic Fas, MAP kinase, and endoplasmic reticulum (ER) stress (8-10).

The relationship between the dysfunction of the NF- $\kappa B$ signaling pathway and the carcinogenesis of stomach cancer was previously reported by several research groups $(11,12)$. $\mathrm{NF}-\mathrm{\kappa B}$ is a ubiquitous dimeric transcription factor that plays pivotal roles in regulating the expression of a multitude of critical genes that regulate cell survival, proliferation, apoptosis, immune responses, and adaptive responses to change the intracellular redox balance (13-16). The constitutive activation of NF- $\mathrm{\kappa B}$, a multi-function nuclear factor, has been suggested to be a hallmark of highly malignant tumors $(17,18)$. Therefore, the inhibition of NF- $\mathrm{KB}$ activation has been reported to be a naturally useful strategy for increasing tissue sensitivity towards cytostatic drug treatment in vitro and in vivo (19).

\section{Materials and methods}

Materials and reagents. Human medium-differentiated gastric cancer SGC-7901 cells were obtained from the Cancer 
Research Institute of Beijing. VES, ethylenediaminetetraacetic acid, dimethyl sulfoxide (DMSO), MTT, Tween-20, sodium dodecyl sulfate (SDS) and PDTC were purchased from Sigma. RPMI-1640, fetal bovine serum (FBS), TRIzol reagent, an Annexin V-FITC apoptosis assay kit, and a total-RNA isolation kit were obtained from Gibco Chemical Co. (Gibco, Rockville, MD, USA). The GeneAmp RNA PCR kit was provided by Perkin-Elmer Life Sciences (Boston, MA, USA). The enhanced chemiluminescence (ECL) kit and the horseradish peroxidase-conjugated antibody were obtained from Amersham Life Science Inc. Taq polymerase was purchased from Roche Molecular Biochemicals (Basel, Switzerland). The LightShift Chemiluminescence EMSA kit was obtained from Pierce (Rockford, IL, USA). Nuclear and cytoplasmic protein extraction kits and a BCA protein assay kit were obtained from Viagene Biotech (Ningbo, China). Rabbit polyclonal antibodies for Bcl-2, Bax, Bak, caspase-8, caspase-9, caspase-3, PARP, NF-кBp65, TATA binding protein (TBP) and $\beta$-actin were purchased from Santa Cruz Biotechnology, Inc. Gene primers of c-IAP1, c-IAP-2, NAIP, survivin, XIAP, and glyceraldehyde-3-phosphate dehydrogenase (GAPDH) for RT-PCR were constructed by Invitrogen.

Cell culture. SGC-7901 were cultured in RPMI-1640 medium supplemented with 5\% FBS, $2 \mathrm{mM}$ glutamine, $100 \mu \mathrm{g} / \mathrm{ml}$ streptomycin, $100 \mathrm{IU} / \mathrm{ml}$ penicillin, and $20 \mu \mathrm{M}$ sodium bicarbonate at $37^{\circ} \mathrm{C}$ in a humidified atmosphere containing $5 \% \mathrm{CO}_{2}$. The culture medium was changed every 2 days.

Cell viability. Cells were plated in 96-well plates, allowed to attach overnight, and treated with various concentrations of VES $(0-160 \mu \mathrm{M})$. Cell viability was estimated using the MTT assay. The medium was aspirated and DMSO was used to dissolve the crystals. Absorbance was measured at $570 \mathrm{~nm}$ using a microplate reader.

Assessment of apoptosis. Apoptosis was quantified using the Annexin V-FITC method. Cells were treated with VES $(40 \mu \mathrm{M})$, and were plated at a seeding density of $10^{5}$ per well in 24-well plates and incubated overnight. Floating and attached cells were harvested and treated according to the manufacturer's instructions.

Protein extraction and western blot analysis. After treatment with or without VES or PDTC, the cells were collected and proteins were extracted. The protein concentration was determined by DC Bio-Rad assay according to the manufacturer's protocol (Bio-Rad Laboratories, Hercules, CA, USA).

For western blot analysis, appropriate amounts of cell lysates $(25-50 \mu \mathrm{g}$ of protein) were separated on $10-15 \%$ SDS-PAGE gel and transferred onto nitrocellulose membranes. The membranes were blocked using 5\% nonfat dry milk and probed using appropriate primary antibodies in blocking buffer overnight at $4^{\circ} \mathrm{C}$. The membranes were then incubated with appropriate secondary horseradish peroxidase-conjugated antibodies and detected by ECL.

Nuclear protein extraction and EMSA. Nuclear protein was extracted from SGC-7901 cells, treated in the presence or absence of VES or PDTC for $24 \mathrm{~h}$, using the nuclear and cyto-
Table I. Sequence of primers used in the present study.

\begin{tabular}{ll}
\hline Primers & \multicolumn{1}{c}{ Sequence } \\
\hline c-IAP-1 & S: 5'-GAAGACATCTCTTCATCGAGG-3' \\
& A: 5'-CCACAGGTGTATTCATCATGAC-3' \\
c-IAP-2 & S: 5'-TCCTAGCTGCAGATTCGTTC-3' \\
& A: 5'-GGTAACTGGCTTGAACTTGAC-3' \\
XIAP & S: 5'-GCACGAGCAGGGTTTCTTTATACTGGTG-3' \\
& A:5'-CTTCTTCACAATACATGGCAGGGTTCCTC-3' \\
NIAP & S: 5'-CTGGGCCTAGATGCAGTTCAG-3' \\
& A: 5'-ACGGCTCATAAGTCACAAAAGTC-3' \\
Survivin & S: 5'-TGCCTGGCAGCCCTTTCTCA-3' \\
& A: 5'-TGGCACGGCGCACTTTCTTC-3' \\
GAPDH & S: 5'-CATCTTCCAGGAGCGAGAT-3' \\
& A: 5'-GCTTCACCACCTTCTTG-3'
\end{tabular}

$\mathrm{S}$, sense; A, antisense.

plasmic protein extraction kits. Concentrations were detected by the BCA assay kit according to the manufacturer's instructions. The NF- $\mathrm{KBp} 65$ combined assay was performed with a biotin-labeled oligonucleotide (5'-AGT TGA GGG GAC TTT CCC AGG C-3'). The complex was separated on $6.5 \%$ acrylamide gel in $0.5 \mathrm{X}$ TBE buffer at $4^{\circ} \mathrm{C}$. Blots were transferred onto $\mathrm{N}+$ nylon membranes according to the manufacturer's instructions.

Evaluation of $m R N A$ transcription by RT-PCR. Total RNA was isolated from $10^{6}$ SGC-7901 cells following treatment according to the manufacturer's protocol. First-strand cDNA was synthesized using the GeneAmp RNA PCR kit. PCR analyses were performed in a final volume of $20 \mu \mathrm{l}$ of buffer containing $1 \mu \mathrm{l}$ of retro-transcription product, deoxyribonucleotide triphosphates (150 $\mu \mathrm{M}$ each), $\mathrm{MgCl}_{2}(2 \mathrm{mM}), 1$ unit of Taq polymerase, and each primer at $1 \mu \mathrm{M}$. Following inactivation at $95^{\circ} \mathrm{C}$ for $1 \mathrm{~min}, \mathrm{PCR}$ amplification was performed under the following reaction conditions: $94^{\circ} \mathrm{C}$ for $1 \mathrm{~min}$, $50^{\circ} \mathrm{C}$ (c-IAP-2), $58^{\circ} \mathrm{C}$ (c-IAP-1, NAIP, XIAP, and GAPDH), $62^{\circ} \mathrm{C}$ (survivin) for $1 \mathrm{~min}, 72^{\circ} \mathrm{C}$ for $1 \mathrm{~min}$, and a final extension at $72^{\circ} \mathrm{C}$ for $5 \mathrm{~min}$. We used 15 cycles of amplification for GAPDH and 30 cycles for the other mRNAs. All PCR products $(10 \mu \mathrm{l})$ were analyzed by electrophoresis on $2 \%(\mathrm{w} / \mathrm{v})$ agarose gel, photographed, and quantified by densitometric scanning. The sequence of primers used for RT-PCR is shown in Table I. The GAPDH gene was used as a loading control.

Statistical analysis. SAS statistical software was used for data analysis. The significance between the control and treated groups was assessed by Student's t-test, and $\mathrm{P}<0.01$ was considered to indicate a statistically significant difference in the experiments.

\section{Results}

Inhibition of growth. The antitumor effects of VES on human gastric cancer SGC-7901 cells were evaluated by MTT assay. 
A

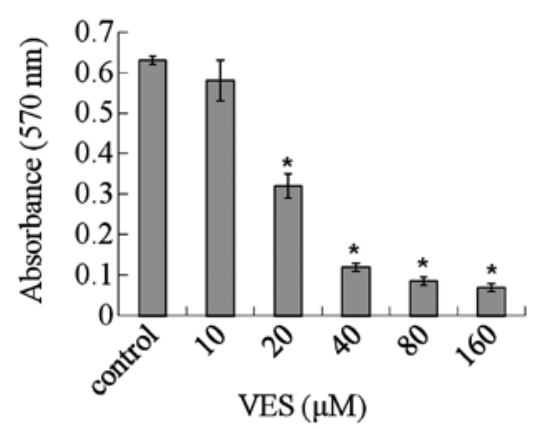

B

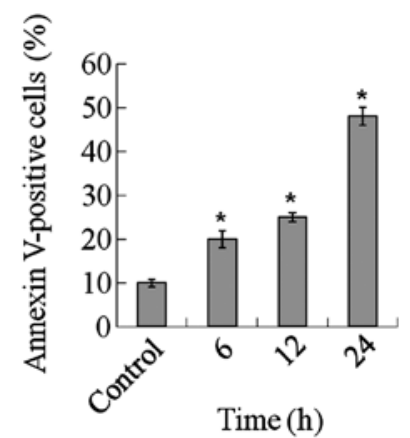

Figure 1. VES inhibits growth and induces apoptosis in SGC-7901 cells. SGC-7901 human gastric cancer cells were treated with different concentrations of VES. (A) Cell viability was determined using MTT assay. (B) Flow cytometric analysis was performed using Annexin V-FITC. Each point represents the mean \pm SD of three independent experiments. Significance was determined using the Student's t-test. ${ }^{*} \mathrm{P}<0.01$ vs. the control group.

$\mathbf{A}$

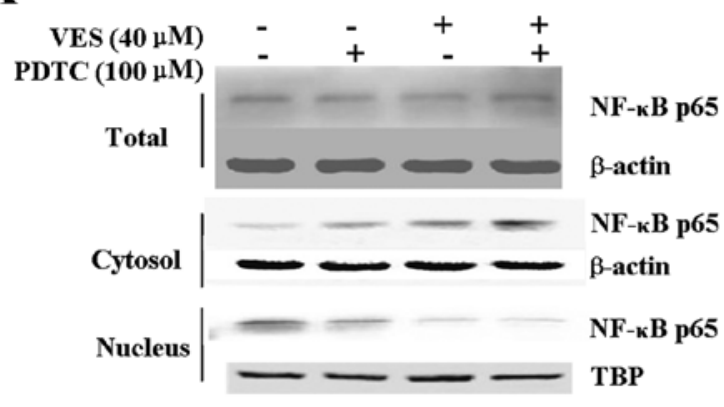

B

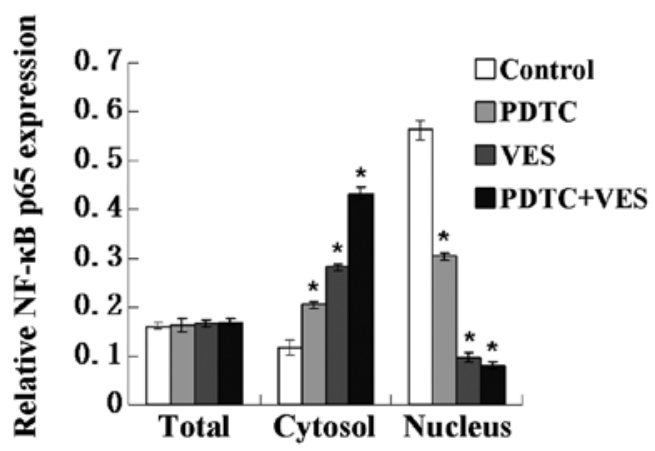

C

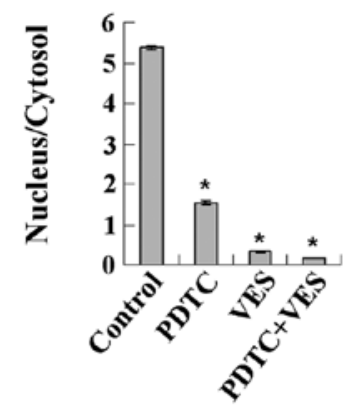

D

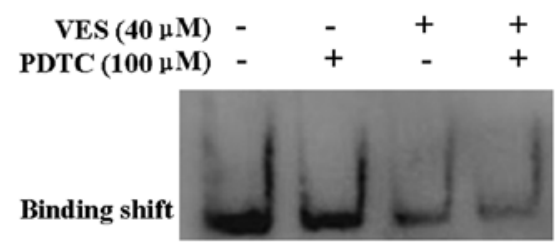

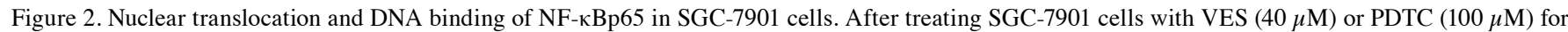
$24 \mathrm{~h}$, total, cytosolic and nucleic proteins were extracted from cells. (A) Proteins were subjected to western blot analysis. (B) Relative densitometry of protein

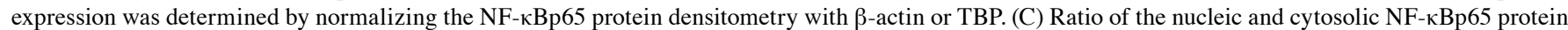
level. The data in (B) and (C) are expressed as the mean \pm SD from three individual experiments. $\beta$-actin was used as an internal loading control for the cytosolic and total preparations, while TBP was used for the nuclear preparation. (D) DNA binding of NF- $\mathrm{\kappa Bp} 65$ was further detected by EMSA. The results obtained are from one representative experiment of three replicates that show similar patterns. ${ }^{\text {}} \mathrm{P}<0.01$ compared with the control group.

Various concentrations of VES $(0-160 \mu \mathrm{M})$ were used to investigate cell viability after treatment. As depicted in Fig. 1A, a significant decrease in cell viability was observed after $24 \mathrm{~h}$ of treatment with 20 to $160 \mu \mathrm{M}$ VES. Furthermore, when the concentration of VES was $>40 \mu \mathrm{M}$, the cells broke into pieces quickly after addition of the agent to the culture medium. Hence, in the present study, moderate concentrations $40 \mu \mathrm{M}$ were chosen to study the antitumor effects of VES in SGC-7901 cells.

Induction of apoptosis. For apoptosis assessment, the exposure of phosphatidylserine on the cell surface was examined by Annexin V staining. As shown in Fig. 1B, flow cytometric analysis revealed that the percentage of Annexin V-positive cells significantly increased following treatment with VES (40 $\mu \mathrm{M})$ for $12 \mathrm{~h}$. Following longer treatment, apoptosis became much more apparent. After VES treatment for $48 \mathrm{~h}$, Annexin V-positive cells accounted for nearly $50 \%$ of all cells counted. Thus, VES leads to apoptotic cell death in human gastric carcinoma cells.

Nuclear translocation and DNA-binding activity of NF- $\kappa B p 65$. To determine whether the activation of $N F-\kappa B$ was involved 
A

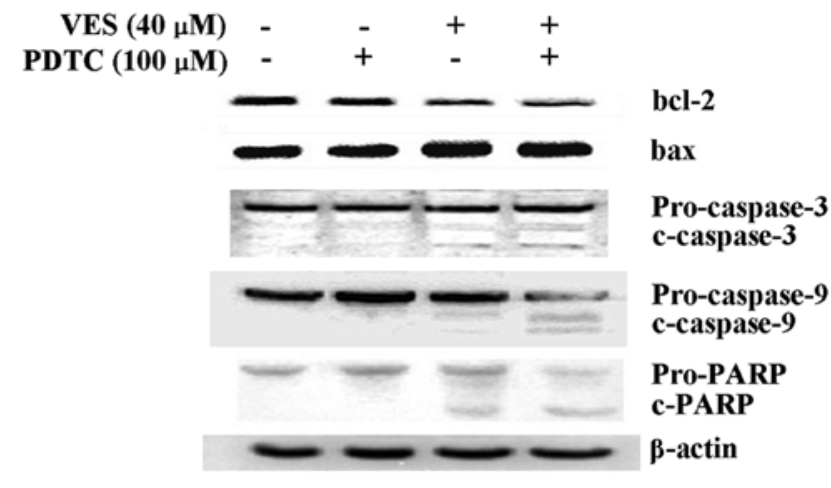

B

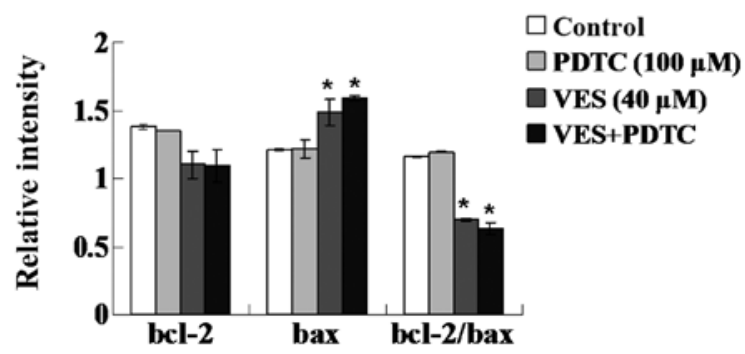

Figure 3. Expression of Bcl-2, Bax and cleavage of caspase-9, caspase-3 and PARP. (A) The samples from Fig. 2 were used to determine the protein expression of Bcl-2 and Bax, as well as caspase-9, caspase-3 and PARP by western blot analysis. (B) Relative densitometry of Bcl-2 and Bax protein expressions were determined by normalizing protein densitometry with $\beta$-actin protein densitometry. The ratio of $\mathrm{Bcl}-2 / \mathrm{Bax}$ is also shown in (B). Data in (A) represent three individual experiments. The data in (B) are expressed as the mean $\pm \mathrm{SD}$ from three individual experiments. ${ }^{*} \mathrm{P}<0.01$ vs. the control group.

in the apoptosis induced by VES in SGC-7091 cells, PDTC, a specific inhibitor of the activation of $\mathrm{NF}-\kappa \mathrm{B}$, was used in the following experiments. Western blotting results showed that PDTC treatment did not influence the expression of the total NF-кBp65 protein level (Fig. 2B). Notably, there was a distinct increase in cytosolic NF- $\mathrm{Bp} 65$ compared with that in the control group (Fig. 2B). However, there was an obvious decrease in the nuclear NF- $\kappa \mathrm{Bp} 65$ protein level. Furthermore, as shown in Fig. 2C, the decrease ratio of the nuclear and cytosolic NF- $\kappa$ Bp65 protein level clearly indicates the possibility that VES induced the nuclear transformation of NF- $\mathrm{Bp} 65$ and PDTC enhanced this transformation.

To examine our hypothesis, $\mathrm{NF}-\kappa \mathrm{B}$ activity was measured by EMSA. The DNA binding of NF- $\kappa \mathrm{B}$ in SGC-7901 cells presented inhibited a decreasing trend (Fig. 2D). As shown in Fig. 2D, PDTC treatment significantly enhanced the decrease of NF- $\kappa \mathrm{B}-\mathrm{DNA}$ binding activity induced by VES in human gastric SGC-7901.

Expression of Bcl-2 family proteins. The protein expression of Bcl-2 family members Bcl-2 and Bax were investigated. VES treatment decreased the protein expression of Bcl-2 and increased the protein expression of Bax. The decreased ratio of Bcl-2 and Bax is shown as in Fig. 3B. The trend became more apparent with PDTC treatment added.

Cleavage of caspase-9, caspase-3 and PARP. Cleavage of caspase-9, caspase-3 and subsequent proteolytic cleavage of
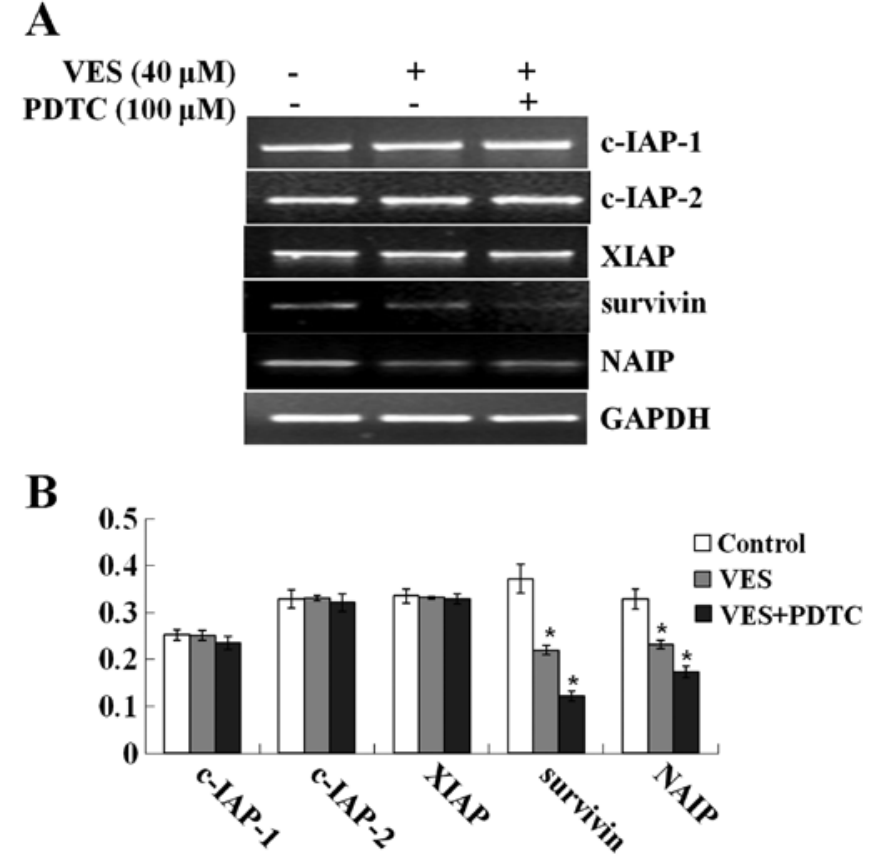

Figure 4. Transcription of IAP genes. (A) mRNA was isolated. Representative analysis of IAP gene mRNA transcription in SGC-7901 cells. (B) RT-PCR with GAPDH primers was performed as a control for the same amount of RNA. The results obtained are from one representative experiment of three replicates that show similar patterns. ${ }^{*} \mathrm{P}<0.01$ compared with the control.

PARP were assessed by western blot analysis. As illustrated in Fig. 3A, VES treatment led to cleavage of caspase-9, caspase-3 and PARP, all of which indicate induction of apoptosis. Notably, pretreatment with PDTC reinforced the VES-induced cleavage.

Transcription of IAP genes. VES or PDTC treatment had no effect on the gene transcription of c-IAP-1, c-IAP-2, and XIAP compared with the control group, whereas gene mRNA levels of survivin and NAIP markedly decreased after treatment with VES (Fig. 4). Furthermore, PDTC intensified the decrease of gene mRNA levels.

\section{Discussion}

The potential anticancer effect of VES in human gastric carcinoma cells has been indicated by our previous in vivo experiment. We found that VES induced apoptosis in SGC-7901 human gastric cancer cells via multiple signaling pathways, including extrinsic Fas, MAP kinase, endoplasmic reticulum (ER) stress, the couple of ER stress and unfolded protein response (UPR) (8-10, 20-22). In addition, VES enhanced DOXO anticancer efficiency via promotion of DOXO influx and suppression of MDR-1 mediated DOXO efflux (21). Recent studies showed that NF- $\kappa$ B was not only related to immune response and inflammatory reaction, but was also involved in regulating cell proliferation, apoptosis and migration (23-25). Involvement of the $\mathrm{NF}-\kappa \mathrm{B}$ signaling pathway in the genesis and progression of malignant gastric cancer led us to undertake this study to explore the mechanism of induction of apoptosis of VES as well as the relationship 
between this mechanism and the NF- $\mathrm{NB}$ signaling pathway in human gastric carcinoma cells.

In this study, moderate concentrations of VES (10-40 $\mu \mathrm{M})$ exhibited apparent growth inhibition effects and induced apoptosis in human gastric carcinoma SGC-7901 cells. The concentration that significantly decreased SGC-7901 cell viability and induced apoptosis was similar to that in other cancer cell cultures, such as leukemia and breast (26-28).

VES treatment caused reductions in nuclear and an increase in cytosolic $\mathrm{NF}-\kappa \mathrm{Bp} 65$ protein levels accompanied by fixedness in total $\mathrm{NF}-\kappa \mathrm{Bp} 65$ protein levels. These results are consistent with those of previous reports $(29,30)$. Several mechanisms for $\mathrm{NF}-\kappa \mathrm{B}$ inhibition are available, such as inhibition of the inhibitor of NF- $\kappa \mathrm{B}(\mathrm{I} \kappa \mathrm{B})$ degradation, phosphorylation of the antagonist of $\mathrm{I} \kappa \mathrm{B}$ by inhibition of $\mathrm{I} \kappa \mathrm{B}$ kinase $\alpha$, and $\mathrm{NF}-\kappa \mathrm{B}$ nuclear translocation (31-34). According to our results, VES may regulate the $\mathrm{NF}-\kappa \mathrm{B}$ pathway by inhibiting the nuclear translocation of NF- $\kappa$ Bp65 in SGC-7901 cells. With the involvement of PDTC, this hypothesis is confirmed.

Overexpression of NF- $\mathrm{B}$-responsive proteins, such as Bcl-2 family members and IAPs, resulting from the constitutive activation of $\mathrm{NF}-\kappa \mathrm{B}$ may critically contribute to the genesis and progression of cancer and represent an important cause of tumor drug resistance $(35,36)$. As previously reported, high $\mathrm{NF}-\kappa \mathrm{B}$ expression is associated with high $\mathrm{Bcl}-2$ expression in breast cancer and leukemic cells (37). Several Bcl-2 family members are known to be involved in the apoptosis-inducing effect of VES in tumor cells in vitro $(38,39)$. We further verified that the intrinsic pathway of cell death is mediated by Bcl-2 family proteins and the balance between pro- and antiapoptotic Bcl-2 family proteins. This balance may terminally determine mitochondrial disruption, cytochrome $c$ release, and caspase activation until apoptosis. Only this ratio dictates whether or not a cell responds to a proximal apoptotic stimulus (40). Caspases are known to be important mediators of apoptosis and contribute to the overall apoptotic morphology by cleaving various cellular substrates $(41,42)$. Activation of caspases is the terminal phase of programmed cell death, and this step is contracted by anti-apoptotic molecules of the Bcl-2 family (43). Our results confirm that VES-mediated changes in Bcl-2 family members trigger the release of mitochondrial cytochrome $c$, which, in turn, accounts for the cleavage of caspase-9, caspase-3 and PARP and ultimately contributes to cell death. Furthermore, this effect is enhanced by PDTC, an inhibitor of $\mathrm{NF}-\kappa \mathrm{B}$.

IAP family proteins play a role in oncogenesis via their effective suppression of apoptosis (44). NF- $\kappa \mathrm{B}$ is known to regulate the expression of anti-apoptotic genes such as IAP-1, IAP-2, XIAP, NAIP and survivin (45). Thus, in this study, whether or not VES treatment regulates the gene transcription of IAP family proteins was determined. Inhibition of constitutive NF- $\mathrm{NBp} 65$ activation could trigger decreases in survivin and NAIP mRNA levels without changing the levels of other inhibitors. Hence, only survivin and NAIP are involved in the apoptosis-inducing effects of VES, which are caused by the inhibition of constitutive NF- $\kappa$ Bp65 activation in VES-treated human gastric carcinoma cells. In contrast to our previous studies carried out using other types of human cancer cells (46). This result indicated that survivin and NAIP may be involved in the VES-induced apoptosis in SGC-7901.
However, the inhibition of nuclear translocation of NF- $\kappa$ Bp65 did not downregulate the expression of all anti-apoptotic genes. There may be other nuclear translocation factors which can regulate the translocation of IAP family genes.

In conclusion, our results demonstrate that VES-induced apoptosis in human gastric carcinoma SGC-7901 cells is accompanied by changes in Bcl-2 family members, cleavage of caspases, and inhibition of the $\mathrm{NF}-\kappa \mathrm{B}$ signaling pathway. Nuclear translocation of NF- $\kappa \mathrm{Bp} 65$ is markedly inhibited after treatment of SGC-7901 cells with VES. Additional studies are required to understand the biochemical mechanisms involved in the induction of apoptosis caused by treatment with VES in human gastric cancer cells. We believe that NF- $\kappa \mathrm{B}$ may be a favorable candidate protein for developing new moleculartargeted therapies against human gastric cancer.

\section{Acknowledgements}

This study was supported in part by grants from the National Natural Science Foundation of China (No. 81172651) to K.W.

\section{References}

1. Foukakis T, Lundell L, Gubanski M and Lind PA: Advances in the treatment of patients with gastric adenocarcinoma. Acta Oncol 46: 277-285, 2007.

2. Tomasetti M, Gellert N, Procopio A and Neuzil J: A vitamin E analogue suppresses malignant mesothelioma in a preclinical model: a future drug against a fatal neoplastic disease? Int $\mathbf{J}$ Cancer 109: 641-642, 2004.

3. Neuzil J, Weber T, Gellert N and Weber C: Selective cancer cell killing by alpha-tocopheryl succinate. Br J Cancer 84: 87-89, 2001.

4. Malafa MP, Fokum FD, Mowlavi A, Abusief M and King M: Vitamin E inhibits melanoma growth in mice. Surgery 131: 85-91, 2002.

5. Kline K, Yu W and Sanders BG: Vitamin E and breast cancer. J Nutr 134: S3458-S3462, 2004.

6. Wu K, Zhao Y, Liu BH, et al: RRR-alpha-tocopheryl succinate inhibits human gastric cancer SGC-7901 cell growth by inducing apoptosis and DNA synthesis arrest. World J Gastroenterol 8: 26-30, 2002.

7. Dong LF, Jameson VJ, Tilly D, et al: Mitochondrial targeting of vitamin $\mathrm{E}$ succinate enhances its pro-apoptotic and anticancer activity via mitochondrial complex II. J Biol Chem 286: 3717-3728, 2011.

8. Wu K, Li Y, Zhao Y, et al: Roles of Fas signaling pathway in vitamin $\mathrm{E}$ succinate-induced apoptosis in human gastric cancer SGC-7901 cells. World J Gastroenterol 8: 982-986, 2002.

9. Wu K, Zhao Y, Li GC and Yu WP: c-Jun N-terminal kinase is required for vitamin $\mathrm{E}$ succinate-induced apoptosis in human gastric cancer cells. World J Gastroenterol 10: 1110-1114, 2004.

10. Huang $X$, Zhang Z, Jia L, Zhao Y, Zhang $X$ and Wu K: Endoplasmic reticulum stress contributes to vitamin $\mathrm{E}$ succinateinduced apoptosis in human gastric cancer SGC-7901 cells. Cancer Lett 296: 123-131, 2010.

11. Guo JL, Zheng SJ, Li YN, et al: Toxicarioside A inhibits SGC-7901 proliferation, migration and invasion via $\mathrm{NF}-\kappa \mathrm{B} / \mathrm{bFGF}$ signaling. World J Gastroenterol 18: 1602-1609, 2012.

12. Long YM, Ye S, Rong J and Xie WR: Nuclear factor kappa B: a marker of chemotherapy for human stage IV gastric carcinoma. World J Gastroenterol 14: 4739-4744, 2008.

13. Zhu BS, Xing CG, Lin F, Fan XQ, Zhao K and Qin ZH: Blocking NF-kappaB nuclear translocation leads to p53-related autophagy activation and cell apoptosis. World J Gastroenterol 17: 478-487, 2011.

14. Li X and Stark GR: NFkappaB-dependent signaling pathways. Exp Hematol 30: 285-296, 2002.

15. Karin M and Lin A: NF-kappaB at the crossroads of life and death. Nat Immunol 3: 221-227, 2002.

16. Gilmore TD: The Re1/NF-kappa B/I kappa B signal transduction pathway and cancer. Cancer Treat Res 115: 241-265, 2003.

17. Bharti AC and Aggarwal BB: Nuclear factor-kappa B and cancer: its role in prevention and therapy. Biochem Pharmacol 64: $883-888,2002$. 
18. Chen W, Li Z, Bai L and Lin Y: NF-kappaB in lung cancer, a carcinogenesis mediator and a prevention and therapy target. Front Biosci 16: 1172-1185, 2011.

19. Sebens S, Arlt A and Schafer H: NF-kappaB as a molecular target in the therapy of pancreatic carcinoma. Recent Results Cancer Res 177: 151-164, 2008.

20. Wu K, Shan YJ, Zhao Y, Yu JW and Liu BH: Inhibitory effects of RRR-alpha-tocopheryl succinate on benzo(a)pyrene (B(a) P)-induced forestomach carcinogenesis in female mice. World J Gastroenterol 7: 60-65, 2001.

21. Zhang X, Peng X, Yu W, et al: Alpha-tocopheryl succinate enhances doxorubicin-induced apoptosis in human gastric cancer cells via promotion of doxorubicin influx and suppression of doxorubicin efflux. Cancer Lett 307: 174-181, 2011.

22. Huang X, Li L, Zhang L, et al: Crosstalk between endoplasmic reticulum stress and oxidative stress in apoptosis induced by alpha-tocopheryl succinate in human gastric carcinoma cells. Br J Nutr 109: 1-9, 2013.

23. Chen X, Kandasamy K and Srivastava RK: Differential roles of RelA (p65) and c-Rel subunits of nuclear factor kappa B in tumor necrosis factor-related apoptosis-inducing ligand signaling. Cancer Res 63: 1059-1066, 2003.

24. Sun SC and Xiao G: Deregulation of NF-kappaB and its upstream kinases in cancer. Cancer Metastasis Rev 22: 405-422, 2003.

25. Lin A and Karin M: NF-kappaB in cancer: a marked target. Semin Cancer Biol 13: 107-114, 2003.

26. Neuzil J, Svensson I, Weber T, Weber C and Brunk UT: alphatocopheryl succinate-induced apoptosis in Jurkat T cells involves caspase-3 activation, and both lysosomal and mitochondrial destabilisation. FEBS Lett 445: 295-300, 1999.

27. Wang XF, Witting PK, Salvatore BA and Neuzil J: Vitamin E analogs trigger apoptosis in HER2/erbB2-overexpressing breast cancer cells by signaling via the mitochondrial pathway. Biochem Biophys Res Commun 326: 282-289, 2005.

28. Yu W, Sanders BG and Kline K: RRR-alpha-tocopheryl succinate-induced apoptosis of human breast cancer cells involves Bax translocation to mitochondria. Cancer Res 63 2483-2491, 2003.

29. Crispen PL, Uzzo RG, Golovine K, et al: Vitamin E succinate inhibits NF-kappaB and prevents the development of a metastatic phenotype in prostate cancer cells: implications for chemoprevention. Prostate 67: 582-590, 2007.

30. Dalen H and Neuzil J: Alpha-tocopheryl succinate sensitises a T Lymphoma cell line to TRAIL-induced apoptosis by suppressing NF-kappaB activation. Br J Cancer 88: 153-158, 2003.

31. Mitsiades N, Mitsiades CS, Richardson PG, et al: The proteasome inhibitor PS-341 potentiates sensitivity of multiple myeloma cells to conventional chemotherapeutic agents: therapeutic applications. Blood 101: 2377-2380, 2003.
32. Zheng B, Georgakis GV, Li Y, et al: Induction of cell cycle arrest and apoptosis by the proteasome inhibitor PS-341 in Hodgkin disease cell lines is independent of inhibitor of nuclear factorkappaB mutations or activation of the CD30, CD40, and RANK receptors. Clin Cancer Res 10: 3207-3215, 2004.

33. Cilloni D, Messa F, Arruga F, et al: The NF-kappaB pathway blockade by the IKK inhibitor PS1145 can overcome imatinib resistance. Leukemia 20: 61-67, 2006.

34. Dai Y, Pei XY, Rahmani M, Conrad DH, Dent P and Grant S: Interruption of the NF-kappaB pathway by Bay 11-7082 promotes UCN-01-mediated mitochondrial dysfunction and apoptosis in human multiple myeloma cells. Blood 103: 2761-2770, 2004.

35. Li $\mathrm{H}$ and Lin $\mathrm{X}$ : Positive and negative signaling components involved in TNFalpha-induced NF-kappaB activation. Cytokine 41: $1-8,2008$

36. Müerköster S, Arlt A, Sipos B, et al: Increased expression of the E3-ubiquitin ligase receptor subunit betaTRCP1 relates to constitutive nuclear factor-kappaB activation and chemoresistance in pancreatic carcinoma cells. Cancer Res 65: 1316-1324, 2005.

37. Viatour P, Bentires-Alj M, Chariot A, et al: NF-kappa B2/p100 induces Bcl-2 expression. Leukemia 17: 1349-1356, 2003.

38. Al-Harbi S, Hill BT, Mazumder S, et al: An antiapoptotic BCL-2 family expression index predicts the response of chronic lymphocytic leukemia to ABT-737. Blood 118: 3579-3590, 2011.

39. Kelly PN and Strasser A: The role of Bcl-2 and its pro-survival relatives in tumourigenesis and cancer therapy. Cell Death Differ 18: 1414-1424, 2011.

40. Oltvai ZN, Milliman CL and Korsmeyer SJ: Bcl-2 heterodimerizes in vivo with a conserved homolog, Bax, that accelerates programmed cell death. Cell 74: 609-619, 1993.

41. Pop C and Salvesen GS: Human caspases: activation, specificity, and regulation. J Biol Chem 284: 21777-21781, 2009.

42. Olsson M and Zhivotovsky B: Caspases and cancer. Cell Death Differ 18: 1441-1449, 2011.

43. Gross A, McDonnell JM and Korsmeyer SJ: BCL-2 family members and the mitochondria in apoptosis. Genes Dev 13: 1899-1911, 1999.

44. Gyrd-Hansen M, Darding M, Miasari M, et al: IAPs contain an evolutionarily conserved ubiquitin-binding domain that regulates NF-kappaB as well as cell survival and oncogenesis. Nat Cell Biol 10: 1309-1317, 2008 .

45. Trocoli A and Djavaheri-Mergny M: The complex interplay between autophagy and NF-kappaB signaling pathways in cancer cells. Am J Cancer Res 1: 629-649, 2011.

46. Neuzil J, Tomasetti M, Zhao Y, et al: Vitamin E analogs, a novel group of "mitocans," as anticancer agents: the importance of being redox-silent. Mol Pharmacol 71: 1185-1199, 2007. 